Article

\title{
The North Cascadia Adaptation Partnership: A Science-Management Collaboration for Responding to Climate Change
}

\author{
Crystal L. Raymond ${ }^{1, *}$, David L. Peterson ${ }^{1}$ and Regina M. Rochefort ${ }^{2}$ \\ 1 USDA Forest Service, Pacific Northwest Research Station, 400 North 34th Street, Suite 201, \\ Seattle, WA 98103, USA; E-Mail: peterson@fs.fed.us \\ 2 National Park Service, 810 State Route 20, Sedro-Woolley, WA 98284, USA; \\ E-Mail: regina_rochefort@nps.gov \\ * Author to whom correspondence should be addressed; E-Mail: craymond@fs.fed.us; \\ Tel.: +1-801-625-5604; Fax: +1-801-625-5723.
}

Received: 31 October 2012; in revised form: 21 December 2012 / Accepted: 27 December 2012 / Published: 8 January 2013

\begin{abstract}
The U.S. Forest Service (USFS) and National Park Service (NPS) have highlighted climate change as an agency priority and issued direction to administrative units for responding to climate change. In response, the USFS and NPS initiated the North Cascadia Adaptation Partnership (NCAP) in 2010. The goals of the NCAP were to build an inclusive partnership, increase climate change awareness, assess vulnerability, and develop science-based adaptation strategies to reduce these vulnerabilities. The NCAP expanded previous science-management partnerships on federal lands to a larger, more ecologically and geographically complex region and extended the approach to a broader range of stakeholders. The NCAP focused on two national forests and two national parks in the North Cascades Range, Washington (USA), a total land area of 2.4 million ha, making it the largest science-management partnership of its kind. The NCAP assessed climate change vulnerability for four resource sectors (hydrology and access; vegetation and ecological disturbance; wildlife; and fish) and developed adaptation options for each sector. The NCAP process has proven to be a successful approach for implementing climate change adaptation across a region and can be emulated by other land management agencies in North America and beyond.
\end{abstract}

Keywords: adaptation; climate change; federal lands; resource management; vulnerability 


\section{Introduction}

The Intergovernmental Panel on Climate Change (IPCC) defines adaptation as "initiatives and measures to reduce the vulnerability of natural and human systems against actual or expected climate change effects" and mitigation as "implementing policies to reduce greenhouse gas emissions and enhance sinks" [1]. Mitigation is critical to reducing atmospheric concentrations of $\mathrm{CO}_{2}$ and thus changes in the climate system. Adaptation, however, will be necessary despite the extent and success of mitigation because of the slow response of the climate system to greenhouse gases that have already been emitted. Even if humans stop emitting greenhouse gasses today, global temperature would continue to rise as the earth equilibrates to new levels of greenhouse gases in the atmosphere [2].

Several United States federal land and resource management agencies have developed strategies for responding to climate change on public lands and are now in the process of implementing these strategies on land management units across the country. Agency strategies focus on increasing climate change awareness, assessing the vulnerability of natural, social, and cultural systems, and developing adaptation strategies to reduce vulnerabilities and increase resilience. Several tools and process have been developed to achieve these goals [3-5], and one that has been shown to be successful is science-management partnerships [6,7]. Although effective collaboration across jurisdictional boundaries has been a significant challenge for federal agencies, science-management partnerships have been valuable in achieving cross-boundary coordination in climate change adaptation.

Both the U.S. Forest Service (USFS) and National Park Service (NPS) have highlighted climate change as an agency priority and issued direction to administrative units for responding to climate change $[8,9]$. The overarching goal of the USFS climate change strategy is to "ensure our national forests and private working lands are conserved and made more resilient to climate change, while enhancing our water resources" [8]. This strategy directs the National Forest System to increase organizational capacity through education and partnerships, assess vulnerability, and implement adaptation into management. Similarly, the NPS Climate Change Response Strategy provides direction for responding to climate change within the agency [9]. It includes goals for science, adaptation, and communication. The similarity in scope and direction of the strategies of the two agencies allows for coordination between them.

The USFS and NPS initiated the North Cascadia Adaptation Partnership (NCAP) in 2010. The main objective of the NCAP was to build a continuing partnership of scientists and resource managers engaged in dialog on climate change issues in the region. The partnership focused on responding to climate change on public lands by (1) increasing climate change awareness among agency staff and partners, (2) assessing vulnerability of natural and cultural resources and infrastructure, and (3) developing science-based adaptation options to reduce adverse effects of climate change and ease the transition to new climate states and conditions.

Developed in response to the proactive climate change strategies of the USFS [8] and NPS [9], the partnership brings together federal agency scientists, academic scientists, and natural resource managers in the region. The NCAP expanded previous adaptation case studies on federal lands to a larger, more ecologically and geographically complex region and extended the approach of science-management partnerships to a broader range of stakeholders. The focal area for the vulnerability assessment and adaptation planning was two national forests (Mount Baker-Snoqualmie 
and Okanogan-Wenatchee) and two national parks (Mount Rainier and North Cascades Complex) in and adjacent to the North Cascade Range, Washington (USA), which comprises a land area of 2.4 million ha, making it the largest science-management partnership of its kind. The partnership includes other local, state, and federal agencies, academic institutions, non-governmental organizations, and tribes.

\section{Methods}

\subsection{North Cascadia Adaptation Partnership Project Area}

Diverse geomorphic processes shaped the landscape of the North Cascade Range, resulting in rugged topography and steep elevation gradients with corresponding gradients in temperature and precipitation. The region has two distinct climatic divisions. On the west side of the Cascades, a temperate, maritime climate dominates, and annual precipitation ranges from 100 to over $250 \mathrm{~cm}$. On the east side of the Cascade Range, the climate is more continental, and annual precipitation is as high as $130 \mathrm{~cm}$ near the crest and as low as $25 \mathrm{~cm}$ east of the Cascade crest. Regionally, most precipitation falls in winter (about $70 \%$ or more of the annual total) and relatively little falls in summer (less than 30\%). Mean annual temperature is similar for both sides of the Cascade Range, but diurnal and seasonal temperature ranges (between low and high daily and seasonal temperatures) are narrower on the west side than the east side of the Cascades. West of the Cascade Range, the Pacific Ocean and Puget Sound moderate the climate, keeping winters relatively warm and summers relatively cool compared to the eastern side of the Cascade Range. Precipitation and temperature also vary with elevation; higher elevations tend to receive more precipitation and experience lower temperatures than lower elevations, resulting in higher winter snowfall and spring snowpack.

Elevation gradients and variable temperature and moisture regimes create many different ecosystems in the North Cascades region, including dry coniferous forests, temperate coniferous rainforests, subalpine forests, riparian forests, and subalpine and alpine meadows and tundra. The region supports a high diversity of native plant and animal species. Low-elevation forests on the west side of the Cascade Range are dominated by western hemlock (Tsuga heterophylla [Raf.] Sarg.), Douglas-fir (Pseudotsuga menziesii [Mirb.] Franco), and western red cedar (Thuja plicata Donn ex D. Don) forests. Low-elevation forests on the east side of the Cascade Range are dominated by Douglas-fir, ponderosa pine (Pinus ponderosa var. ponderosa Douglas ex P. Lawson and C. Lawson), grand fir (Abies grandis [Douglas ex D. Don] Lindl.), and western larch (Larix occidentalis Nutt.). Subalpine forests are dominated by mountain hemlock (Tsuga mertensiana [Bong.] Carrière), Pacific silver fir (Abies amabilis Douglas ex J. Forbes), and subalpine fir (A. lasiocarpa [Hook.] Nutt.) on the west side and by subalpine fir, Engelmann spruce (Picea engelmannii Parry ex Engelm.), and subalpine larch (L. lyallii Parl.) on the east side.

The region is also home to a complex system of streams, rivers, lakes, and wetlands that are fed by an extensive glaciated area, permanent snowfields, and high winter precipitation. Waterways in the region provide water and hydroelectric power for downstream communities, including the Seattle-Tacoma metropolitan area with a population of 3.5 million people. They also provide important habitat for salmon and other cold-water fish species, several of which are listed as threatened and 
endangered species. The region includes an extensive network of roads and trails that intersect waterways in numerous locations with bridges and culverts that must be managed to maintain access and reduce impacts on aquatic habitat. The transportation system was built to provide access for natural resource extraction, but it is now used primarily for fire suppression and recreation. Visitation to the national forests and national parks in the region is some of the highest in the nation, creating high demand for year-round access for recreation.

\subsection{Regional Climate Change Projections for the Pacific Northwest}

Several regional assessments have used downscaled climate projections from global climate models (GCMs) to project changes in regional temperature and precipitation [10,11]. Regionally, the average response of a 10-model ensemble for the A1B emissions scenario [12] indicates that temperature is expected to continue to increase in the region, warming on average $2.1^{\circ} \mathrm{C}$ by the 2040 s (mean of years between 2030-2059), and $3.8{ }^{\circ} \mathrm{C}$ by the 2080s (mean of years between 2070-2099) [11]. This projection puts the 2040s average temperatures at the upper end of the historical range and 2080s average temperatures outside the historical range (1970-1999). The seasonality of changes in temperature is important for understanding effects on hydrology, snowpack, and ecological processes. Temperature is projected to increase in all seasons with the largest increases projected for summer (June, July, August).

The range of projections of future precipitation is large, and output varies among GCMs with some projecting increases in annual precipitation and others projecting decreases [10,11]. For the A1B emissions scenario and 10-model ensemble, no change in annual precipitation is projected for the 2040 s and a $2 \%$ increase is projected for the 2080s [11]. Changes in seasonal, rather than annual, precipitation may be more perceptible and important for understanding the effects of altered precipitation regimes on hydrological process such as streamflow, snowpack, and soil moisture. Increased precipitation is projected for all seasons except summer, in which precipitation is projected to decrease $10 \%$ by the 2040 s.

Changes in temperature and precipitation have implications for hydrologic and ecological processes $[13,14]$ and will affect natural resources throughout the region. In the North Cascades, one of the most significant changes will be a shift to more winter precipitation falling as rain rather than snow, leading to reduced snowpack, earlier snowmelt, and shifts in the timing of peak streamflow from late spring or early summer snowmelt events to late autumn and early winter [13]. These effects are expected to be most pronounced in mid-elevation river basins where winter precipitation currently falls as a mix of rain and snow. Extreme flood events associated with peak flows are projected to increase throughout much of the North Cascades. The region is projected to experience declines in low flows in summer, particularly on the west side of the Cascade Range. With more winter precipitation as rain, winter soil moisture is projected to increase, particularly at higher elevations and in the east central area. Conversely, summer soil moisture is projected to decline due to a combination of lower snowpack, lower summer precipitation, and higher summer temperature. 


\subsection{North Cascadia Adaptation Partnership Process}

The North Cascades has a complex history of land use and ownership, but much of the area is now managed by the USFS and NPS. Adjoining lands are owned and managed by state agencies (Washington Department of Natural Resources and Washington Department of Fish and Wildlife), city and county municipalities, and Native American tribes (Figure 1). A regional response to climate change is important in the North Cascades because of the diversity of adjoining land ownerships. The NCAP was a participatory process that brought together federal, state, and local resource management agencies, as well as user groups, to share information and collaborate on a regional response to climate change. As a science-management partnership, the NCAP also brought together scientists from agencies and academic institutions to share information on climate change projections and effects on natural resources. This was a two-way dialog in which scientists shared the latest scientific information on climate change, and managers shared expert knowledge on their local systems and management practices. Through this dialog, participants identified climate change vulnerabilities and adaptation options to reduce these vulnerabilities.

Figure 1. National Park Service and U.S. Forest Service lands compose the focal area of the NCAP, but these lands are surrounded by other municipal, state, federal, private, and tribal ownerships. NCAP includes many of these stakeholders in an effort to use an "all lands" approach to adapting to climate change.

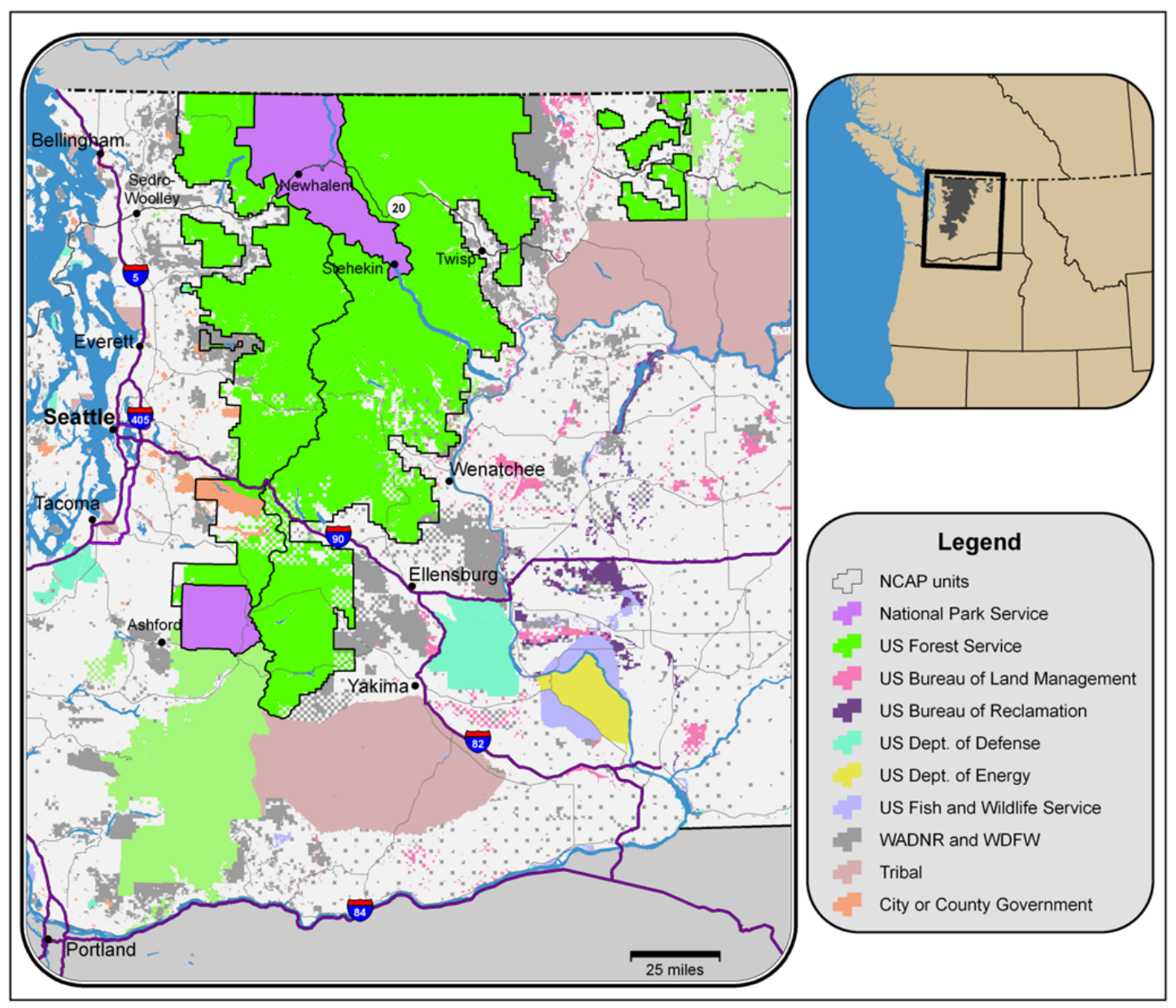




\subsubsection{Increasing Climate Change Awareness and Building Organizational Capacity}

One-day educational workshops on climate change, one for each national forest and national park, initiated the NCAP process. Scientists from the USFS, NPS, other agencies, and academic institutions presented the latest scientific information on projected changes in climate and effects on natural resources. The objectives of these initial educational workshops were to provide an opportunity for resource managers to interact with climate change scientists, voice current and future management challenges, and develop a common understanding of local climate change effects on natural resources. Climate science information focused on local and regional effects in order to ensure relevance to local land management needs.

\subsubsection{Assessing Vulnerability}

Building on the educational component of NCAP and using regional assessments of projected changes in climate, we assessed the vulnerability of natural resources, infrastructure, and current management objectives. This was accomplished through a series of four two-day workshops focused on (1) hydrology, roads, and access; (2) vegetation and ecological disturbances; (3) wildlife and wildlife habitat; and (4) fish and fish habitat. These resource sectors were selected based on their importance in the region and current management challenges. They are similar to the resources that were the focus of a previous partnership for the Olympic Peninsula, Washington [7], but differ in two ways, reflecting differences in the ecology and predominant use of public lands in the North Cascades. USFS and NPS managers in the NCAP emphasized concerns about changes in ecological disturbances (fire and insects) and challenges associated with maintaining road and trail access for the large numbers of recreational users that visit the area. During each workshop, scientists and resource managers discussed climate change effects and current management practices, followed by facilitated discussions to identify key impact pathways and vulnerabilities.

Vulnerability assessments typically involve three aspects of resources or systems: exposure, sensitivity, and adaptive capacity [14]. Exposure is the degree to which the system is exposed to changes in climate. Sensitivity is an inherent quality of the system that indicates the degree to which it could be affected by climate change. Adaptive capacity is the ability of a system to respond and adjust to the exogenous influence of climate. Vulnerability assessments can be both qualitative and quantitative and focus on whole systems or individual species or resources [15]. For the NCAP, we used expert knowledge and a review of the scientific literature to assess vulnerability. To the greatest extent possible, we focused on effects and projections specific to the NCAP region and used the finest resolution projections that are scientifically valid. Several tools and databases are available for systematically assessing sensitivity and vulnerability of species. We used the Climate Change Sensitivity Database [16] to assess the sensitivity of specific wildlife species of concern.

Adaptive capacity is the ability of species and ecosystems to respond to changes in climate, but it also includes the capacity of organizations to accommodate changes in management practices necessary to respond to climate change. To assess adaptive capacity, we reviewed current USFS and NPS management objectives and practices to determine barriers for adapting to climate change and information needs for building agency capacity to respond to climate change. 
In the vulnerability assessment, we considered uncertainty in future climate in several ways. We used projected changes in climate and hydrology from a range of models [3] — an ensemble of 10 GCMs and two bracketing GCMs that give a range of climate futures for the region [11]. Climate projections included temperature and precipitation, as well as variables simulated with a hydrologic model including snow depth, soil moisture, flood frequency, and streamflows. During the workshops, climate scientists presented limitations and uncertainty associated with these GCM projections. We also addressed uncertainty by focusing on similarities among models [3]. Although these projections show a range of future climate, many variables important for resource management are similar among projections [3]. The GCM projections differ in the magnitude of changes in temperature, snowpack, soil moisture, and flood risk, but generally agree on the direction of change, with the exception of precipitation. For the PNW, some GCMs project decreases in annual precipitation and others project increases. However, many hydrologic variables important for planning (e.g., flood risk) are driven by temperature as much as precipitation, thus increasing certainty in these projections. Another source of uncertainty is the coarse resolution of climate projections relative to the information needs of land managers. The participatory process of NCAP made it possible to use local expert knowledge of land managers to conceptually downscale projections. Local experts can identify what coarse scale projections are likely to mean for the local areas that they manage.

\subsubsection{Adapting Natural Resource Management}

After identifying key vulnerabilities for each resource sector, we used facilitated discussions among scientists and resource managers to identify potential adaptation options. Abundant literature is available summarizing general principles for adapting resource management practices to a changing climate [17-19]. However, most of this literature is conceptual [20], partially because it is difficult to scientifically test the efficacy of adaptation actions and because few efforts have connected adaptation concepts with specific resources, places, and people. By working collaboratively with scientists and managers and focusing on a specific region, the goal of the NCAP workshops was to go beyond general concepts to identify specific actions that could be implemented into projects and plans. Facilitators captured information generated during the workshops with a set of spreadsheets [21]. Initial results from the workshops were augmented with a review of the literature and continued dialog with USFS and NPS resource managers.

For each workshop, participants identified strategies (general approaches) and tactics (on-the-ground actions) for adapting management practices. Adaptation strategies included actions to create resistance, promote resilience of resources and ecosystems, and enable natural and built systems to respond to changes in climate [19]. All three types of adaptation strategies were discussed because each is useful for different time frames and depending on the social, political, or economic value of the resources [3]. Strategies for increasing resistance include actions that enable natural and built systems to maintain their current state despite changes in climate. Resistance strategies may be most useful for high value resources, the loss of which is politically or socially unacceptable, such as endangered species or historic and cultural landmarks. Resistance strategies are most effective in the short-term and may need to be superseded by strategies for resilience or response as changes in climate are realized. Adaptation strategies most often focused on resilience because increasing resilience 
involves actions that are robust to a range of future climates. Increasing resilience increases the flexibility of natural or built systems so that they are more able to return their previous state after disturbance [3]. Resilience strategies can be useful in the short or long term. Substantial changes in climate may require response strategies, which facilitate transitions to new states with the recognition that maintaining previous states may no longer be feasible [3]. Response strategies involve proactive management actions that are the greatest departure from current management. In some cases, workshop participants identified time frames or events that would require adaptation to shift from one strategy to another.

The NCAP considered uncertainty in adaptation planning, as well as in the vulnerability assessment. Participants focused on adaptation options for changes in climate that are more certain than others. For example, increases in flood risk are relatively certain in the PNW, thus land managers felt that sufficient data existed to develop specific adaptation tactics to reduce adverse effects of future flooding. In identifying adaptation options, participants also used historical climatic variability to inform the types of events that may become more common in the future. Climatic variability is high in the PNW, particularly for precipitation. Although it is important to recognize that the past is no longer a predictor of the future, extreme events observed in the historical record can inform the types of events to which resource management will need to adapt [3]. To move forward with adaptation planning despite uncertainty, participants focused on robust adaptation actions, actions that will increase resilience of natural resources to a wide range of possible climate futures. On the other hand, for resources for which participants felt the effects of climate change were highly uncertain, they identified research and monitoring needs to inform potential adaptation options.

The NCAP process was completed over two years from the initiation of the partnership to completion of a federal government report detailing the process and results. The four educational workshops were completed in three months. The four vulnerability and adaptation workshops were completed in six months. The NCAP partnership, workshops, and final report were organized by one full-time post-doctoral researcher, with additional time contributed by one NPS and one USFS scientist. Regional agency and academic scientists contributed time by presenting at workshops and contributing expertise to the working sessions and final report. The final report was completed in eight months. A scientific expert for each of the four resource sector was contracted to summarize projections of changes in climate and effects on natural resource for the final report. The total cost of the project was approximately $\$ 200,000$ over two years, excluding contributions of USFS and NPS unit staff salaries and travel for participating in workshops.

\section{Results and Discussion}

\subsection{Increasing Climate Change Awareness and Building Organizational Capacity}

One element of increasing organizational capacity is providing education and training on climate change science and their effects on resources. The NCAP process built organizational capacity by providing education at two levels. On one level, the initial one-day educational workshops provided basic climate change science information at a level that was accessible to all, including those without any knowledge of climate science. Over 300 USFS and NPS employees from all sectors of the 
workforce and their partners attended the workshops, which were supported by unit supervisors. On another level, the two-day workshops for each of the four resource sectors further built organizational capacity by providing more in-depth information on climate change science and effects on specific resources. These workshops were attended by a smaller group of resource specialists, who are specifically tasked with considering climate change in their management actions. During the workshops, resource specialists were also introduced to principles, tools, data, and processes for assessing vulnerability and adaptation planning, thus increasing their capacity to address climate change in management plans and projects.

In 2012, the two national forests in the NCAP develop Climate Change Actions Plans and responses to the USFS Climate Change Performance Scorecard [8]. These documents provide evidence of the NCAP's success at building organizational capacity. The USFS performance scorecard requires national forest units to build organizational capacity and develop partnerships to improve the ability of their unit to respond to climate change. The two national forests cited high staff participation in the NCAP workshops and engagement in the partnership as evidence of building capacity and partnerships to address climate change. The forests identified the NCAP as a key partnership for enabling resource managers to collaborate with scientists and gain access to climate change information.

Although a similar metric was not available to evaluate capacity building for NPS units, anecdotal evidence indicates that the NCAP accomplished this in several ways. In addition to providing education on climate change, the NCAP workshops enabled NPS managers to access climate data such as spatially explicit projections of changes in flood risk, streamflow, snow depth, and soil moisture, as well as information on how to use of these data for planning. Based on informal feedback, the presentations of climate science in the workshops and final report provided NPS managers with context and a scientific basis to support the recent changes and trends they are observing. The NCAP increased awareness and raised the importance of climate change within the NPS units, thus enabling managers to identify climate change as a priority in staff programs of work and increase the urgency in addressing it in management. Information gathered through the NCAP workshops will have cascading effects and raise awareness beyond those who attended the workshops. Through the NCAP process, participants shared information on additional tools and methods that could be used to assess vulnerability in greater depth or to assess vulnerability of resources and systems not included in the initial assessment. Climate change education for the general public was beyond the scope of the NCAP, but knowledge generated through this process could be used for outreach and interpretive materials. We did engage a larger public audience in the workshop on hydrology and access by including several user groups, which was important for this issue because of its direct relevance to the public. During this workshop, participants discussed the potential to work with user groups to deliver information on the additional effects of climate change on access and on efforts by the USFS and NPS to mitigate those effects.

We focused as much on partnership and process as on products because of the importance of partnerships in successful agency responses to climate change. The result of the NCAP process was an inclusive partnership of scientists and managers from multiple agencies, organizations, and academic institutions. Both the USFS and NPS climate change response strategies emphasize the need to build partnerships and incorporate climate change considerations into existing partnerships. The NCAP built agency capacity to respond to climate change challenges that cross jurisdictional 
boundaries by increasing interaction among managers from different agencies who are working on similar challenges. The NCAP increased awareness among resource managers of differences in agency missions and objectives that may require different responses, as well as similarities that may provide opportunities for a coordinated approach. The NCAP process strengthened collaboration between land management agencies, increasing capacity for a coordinated regional response to climate change. Furthermore, climate science information is emerging and changing rapidly. Through the NCAP, resource managers engaged with scientific experts on climate change and built the connections necessary to incorporate rapidly changing climate science into management practices.

\subsection{Vulnerabilities and Adaptation Options for Roads, Trails, and Sustainable Access}

The transportation system in the North Cascades has several qualities that make it inherently sensitive to changes in climate. Many forest roads were not built with the intention that they would be permanent and were not constructed to design standards promoting longevity. For example, many culverts were designed to withstand only a 25-year flood. Roads and trails were also built in valley bottoms and along waterways because of the steep, rugged terrain. Managers are already coping with a backlog of flood-related damage from extreme flood events and large landslides in the last decade. Furthermore, road repair and maintenance on the national forests was funded historically by revenue from timber sales, which has greatly declined in recent decades at the same time that access for recreation has increased. These factors limit the capacity of the agencies to adapt to climate change, but they increase the importance of considering climate change in road design and maintenance decisions.

Workshop participants identified four main impact pathways through which access (roads, trails, and infrastructure) in the North Cascades is vulnerable to changes in climate. Higher peak flows in autumn and winter [22,23] will increase flood risk to roads, trails, stream-crossing structures, and infrastructure. Increased soil moisture in winter is likely to reduce slope stability and increase the likelihood that landslides and slope failures will damage roads and trails. Reduced snowpack and earlier snowmelt will increase the length of the snow-free season [13], potentially increasing visitation early and late in the season. Lower low flows in summer will reduce water availability for infrastructure, visitor use, and seasonal residents [23].

Adaptation strategies and tactics to reduce these vulnerabilities include actions to resist the effects of flooding, increase the resilience of the transportation system, and facilitate the transition to systems that can be sustained under new climatic conditions (Table 1). Resistance strategies to adapt to higher peak flows and landslide risk involve protecting existing infrastructure in place. These strategies may be effective only in the short term. Strategies for increasing resilience and enabling response will become increasingly important as climate changes [19]. Resistance strategies can be initial adaptation actions that bridge the gap until more resources become available. Resilience and response strategies involve larger changes to the design and location of infrastructure. These strategies are more feasible in the long term and can be implemented in response to damage by floods and landslides or when infrastructure is slated for repair or replacement. 
Table 1. Adaptation strategies and tactics for transportation and access in the North Cascades.

\begin{tabular}{|c|c|}
\hline Adaptation strategy & Adaptation tactics \\
\hline $\begin{array}{l}\text { Increase resistance to higher } \\
\text { peak flows where waterways } \\
\text { cross roads. }\end{array}$ & $\begin{array}{l}\text { - Install hardened stream crossings. } \\
\text { - Continue to use grade control structures, humps, and water bars to reduce } \\
\text { velocity and redirect flow. } \\
\text { - Use rip-rap or vegetation to stabilize banks near resources or infrastructure. } \\
\text { - Consider using more engineered log jams to redirect flows. } \\
\text { - Request additional funding to prepare for more trail and bridge failures. }\end{array}$ \\
\hline $\begin{array}{l}\text { Increase resilience of stream } \\
\text { crossings, culverts, and } \\
\text { bridges to higher peaks flows. }\end{array}$ & $\begin{array}{l}\text { - Complete unit wide inventory of culverts and bridges. } \\
\text { - Continue to replace culverts with higher capacity culverts. } \\
\text { - Raise trail bridges higher above waterways. } \\
\text { - Consider designing culverts for projected, rather than historical, peak flows. } \\
\text { - Prioritize structure replacement in high risk (mid-elevation) basins. } \\
\text { - Continue to upgrade trail bridges with stronger rot resistant materials. } \\
\text { - Consider increasing the height of bridges above waterways. }\end{array}$ \\
\hline $\begin{array}{l}\text { Facilitate the response to } \\
\text { higher peak flows by reducing } \\
\text { the road and trail system. }\end{array}$ & $\begin{array}{l}\text { - Reroute roads and trails and move infrastructure out of floodplains. } \\
\text { - Continue to decommission roads and trails with high risk and low access. } \\
\text { - Convert use of at risk roads to other uses (e.g., from vehicle to bicycle or foot). } \\
\text { - Continue to relocate trail bridges to locations with stronger parent material. } \\
\text { - Continue to reroute trails to locations that eliminate the need for bridges. } \\
\text { - Change user expectations of access with public outreach and education. }\end{array}$ \\
\hline $\begin{array}{l}\text { Increase resistance to } \\
\text { landslides by protecting roads } \\
\text { and infrastructure in place. }\end{array}$ & $\begin{array}{l}\text { - Increase road and trail maintenance frequency. } \\
\text { - Stabilize slopes mechanically or with vegetation. } \\
\text { - Improve drainage. } \\
\text { - Alter road surface type and grade. } \\
\text { - Elevate roads to allow landslides to pass underneath. }\end{array}$ \\
\hline $\begin{array}{l}\text { Facilitate response to higher } \\
\text { landslide risk by relocating } \\
\text { infrastructure out of high } \\
\text { risk areas. }\end{array}$ & $\begin{array}{l}\text { - Decommission roads and trails with low access and high landslide risk. } \\
\text { - Locate new construction away from areas of high landslide risk. } \\
\text { - Collaborate with partners to compare maps of current landslide damage with } \\
\text { maps of soil moisture and landforms to identify sensitive areas. }\end{array}$ \\
\hline $\begin{array}{l}\text { Maintain safe access at the } \\
\text { beginning and end of the } \\
\text { summer recreation season. }\end{array}$ & $\begin{array}{l}\text { - Increase public education on the risks of early and late season access. } \\
\text { - Limit access when public safety is a concern. } \\
\text { - Open trails, campgrounds, and facilities earlier in the season to accommodate } \\
\text { higher visitation. } \\
\text { - Implement adaptive management - alter management as season length changes. }\end{array}$ \\
\hline $\begin{array}{l}\text { Maintain sufficient water } \\
\text { supply to meet demand during } \\
\text { low dry-season flows. }\end{array}$ & $\begin{array}{l}\text { - Investigate alternative water sources (e.g., groundwater). } \\
\text { - Consider constructing new wells, cisterns, and reservoirs. } \\
\text { - Increase water storage with artificial storage infrastructure. } \\
\text { - Import water from outside of the region. }\end{array}$ \\
\hline $\begin{array}{l}\text { Increase resilience to low } \\
\text { dry-season flows with water } \\
\text { conservation. }\end{array}$ & $\begin{array}{l}\text { - Educate the public about water shortages and conservation and reduce user } \\
\text { expectations of water availability. } \\
\text { - Reduce water provided in campgrounds and other facilities. } \\
\text { - Reduce campground capacity and close facilities to decrease water demand. }\end{array}$ \\
\hline
\end{tabular}




\subsection{Vulnerabilities and Adaptation Options for Vegetation and Ecological Disturbances}

Participants in the vegetation workshop identified several changes in climate that will have implications for vegetation and ecological disturbances. Warmer temperatures and decreased snowpack, without increases in summer precipitation, will cause a longer duration of low soil moisture throughout most of the North Cascades [13]. Warmer temperatures will also increase potential evapotranspiration, the amount of water that can be evaporated from land and transpired from plant tissues. When potential evapotranspiration exceeds actual evapotranspiration, water balance deficit exists. Water balance deficit is projected to increase in the eastern part of the region and locally increase or decrease in the western part of the region [13].

Most low-elevation forests that currently experience water limitations will likely experience more severe or longer duration water limitation in the future. The short-term effects on water-limited forests will likely be decreased seedling regeneration and tree growth and increased mortality (especially for seedlings). Moisture stress will likely increase tree vulnerability to insects and some pathogens. Warmer, drier summers in the North Cascades will almost certainly increase the area burned by fire [24], and may also increase the frequency, size, and severity of fires. Warmer, drier conditions and increased rates of disturbance are likely to provide a competitive advantage to invasive species. Invasive species typically have broad climatic tolerances and life history traits that facilitate rapid dispersal and growth in response to resource availability created by disturbance [25].

In contrast, current energy-limited forests in the North Cascades will likely become less energy limited, and the effects of climate change will depend on the degree of seasonal water limitation. Increased length of the growing season, warmer temperatures, and increased soil moisture will lower environmental barriers to tree establishment in subalpine and alpine ecosystems. Loss of tundra, expansion of tree islands in the subalpine ecosystems, and rising treelines may be the most visible changes in high-elevation forests [26]. Shifts in distributions of herbaceous vegetation, shrubs, and sedges may be less visible than shifts in altitudinal treeline, but observational studies and experiments suggest significant future changes above the treeline [27].

In response to these vulnerabilities, workshop participants identified adaptation strategies and tactics to increase the resilience of forest and subalpine ecosystems (Table 2). The sensitivity of forest ecosystems to water limitations and fire and insect disturbances is exacerbated by current stressors such as overly dense stands and reduced species diversity caused by current fire suppression and past fire exclusion, selective harvests, and planting of monocultures. In historically fire-adapted forests, the effects of climate change will depend on the degree to which past harvesting and fire exclusion have affected stand density and species composition [28]. Climate-driven increases in insect outbreaks and fire will likely be more evident in forests where tree density and fuels are sufficiently developed and fire intolerant species have increased in abundance. Adaptation tactics have therefore focused on reducing these stressors, because these are robust tactics that can create ecosystems that will have greater resilience to a range of future climates. Similarly, existing invasive species will reduce the ability of natural vegetation to adapt and respond to changes in climate and were thus a focus of adaptation tactics (Table 2). 
Table 2. Adaptation strategies and tactics for vegetation and disturbances in the North Cascades.

\section{Adaptation strategy}

Increase resilience of forest stands to insect and pathogen disturbances by increasing tree vigor.
Increase resilience to large and extensive fires and insect and pathogen outbreaks.

Plan and prepare for more frequent and severe fire and greater area burned.

\section{Adaptation tactics}

- Accelerate development of late-successional forest conditions by reducing density and diversifying forest structure by thinning.

- Harvest to variable densities.

- Reduce density of post-disturbance artificial regeneration.

- Plant resistant species or genotypes where species-specific insects or pathogens are a concern (e.g., white pine blister rust).

- Increase stand-scale biodiversity and minimize monocultures.

- Design forest gaps that create establishment opportunities.

- Increase diversity of patch sizes.

- Consider planting desired species (assisted migration) rather than relying on natural regeneration and migration.

- Consider climate change in fire management plans.

- Anticipate more opportunities to use wildfire for resource benefits.

- Plan post-fire responses for large fires in systems not adapted to fire.

- Consider using prescribed fire to facilitate transitions to new fire regimes in mixed severity fire regimes.

- Consider planting fire-tolerant species after fire in areas with increasing fire frequency.

- Manage for future range of variability in structure and species.

Increase ecosystem resilience through post-fire management.

- Consider climate change in post-fire rehabilitation.

- Anticipate greater need for seed sources and propagated plants.

- Plant native grasses after fire to compete with invasive grasses.

- Increase post-fire monitoring in systems not currently monitored.
Prevent widespread outbreaks of invasive species and invasive species establishment after disturbances.

- Include invasive species prevention strategies in all projects.

- Increase regular inventory to detect new populations or species.

- Coordinate invasive species management, funding, and program support among agencies.

- Plan for extreme events and events with low probability.

- Maintain permits for aggressive herbicide or burning treatments.

- Consider assisted migration.

- Emphasize use of species in restoration projects that will be robust to warmer temperatures and lower soil moisture.

- Plant species from appropriate seed zones that are genetically adapted to warmer temperatures and lower soil moisture.

Increase understanding of changes in

- Monitor and attribute changes in tree distribution and tree establishment patterns at tree line.

- Expand long-term subalpine and alpine monitoring programs.

- Coordinate among agencies to improve analysis of long-term changes in vegetation. 


\subsection{Vulnerabilities and Adaptation Options for Wildlife and Wildlife Habitat}

Many animal species in the North Cascades are adapted to relatively cool, moist environments and, in particular, cold, wet winters and warm, dry summers. Although this basic climatic pattern may be reinforced by increases in winter precipitation and decreases in summer precipitation, higher temperature coupled with drier summers will directly affect wildlife species and their habitats. Workshop participants evaluated the sensitivity of wildlife species of concern in the North Cascades. Some species will be less vulnerable because they are generalists, are less physiologically sensitive to changes in temperature and moisture, can more easily disperse to new locations, or occupy habitats that are likely to be more resilient to climate change. Other species that are specialists, limited in their dispersal abilities, or occupy narrow climatic niches or rare habitats are likely to be more vulnerable. Vulnerability of wildlife will also greatly depend on changes in their habitat. Participants assessed the vulnerabilities of four general habitat types: wet maritime forests, dry fire-adapted forests, montane meadows, and wetlands. Climate-driven changes in plant species distributions and fire and hydrologic regimes will affect habitat, food resources, and hence reproduction and mortality rates of many species. Participants identified adaptation options for the four habitat types and the species that depend on them (Table 3). Many adaptation options for management of wildlife habitat were complementary to adaptation options for managing vegetation.

In both wet maritime forests and dry fire-adapted forests in the North Cascades, one the most important vulnerabilities will be changes in disturbance regimes. More area burned by wildfire and increasing fire severity will indirectly affect wildlife by altering food resources and decreasing the area and connectivity of late-successional forest habitat, and increase habitat for species associated with early-successional habitat. These changes will benefit species that are well adapted to fire-prone habitat, but reduce habitat for two endangered species in the region, the northern spotted owl (Strix occidentalis caurina Merriam) and marbled murrelet (Brachyramphus marmoratus Gmelin), which require late-successional forests. Increasing resilience of late-successional habitat to climate-driven changes in fire regimes will facilitate adaptation for these species (Table 3).

Wetland habitats and associated species are already experiencing threats from disease, pollution, and habitat loss and fragmentation - threats that may be exacerbated by climate change [29]. The combined effects of warmer summer temperatures, changes in the seasonality of precipitation, and reduced snowpack may cause earlier drying of ephemeral streams and ponds and receding shorelines [29]. Amphibian species that depend on wetland habitats are expected to be some the most sensitive species to changes in climate because of their permeable skins and moisture requirements, as well as their bi-phasic life histories requiring water for breeding and upland habitats for other activities. In the North Cascades, amphibian species such as the northern red-legged frog (Rana aurora Baird and Girard) are likely to be sensitive to higher temperature and drier conditions in summer months [30]. Tactics to facilitate adaptation for wetland species include reducing non-climatic threats, such as invasive species, disease, artificial barriers to water flow, and recreation traffic, and increasing the resilience of wetland habitats to changes in temperature and moisture regimes (Table 3). 
Table 3. Adaptation strategies and tactics for wildlife and wildlife habitat in the North Cascades.

\begin{tabular}{|c|c|}
\hline Adaptation strategy & Adaptation tactics \\
\hline $\begin{array}{l}\text { Increase resilience of } \\
\text { late-successional habitat in wet } \\
\text { maritime forests. }\end{array}$ & $\begin{array}{l}\text { - Increase landscape biodiversity and heterogeneity by modifying } \\
\text { species composition. } \\
\text { - Increase diversity of age classes and restore patch mosaic. } \\
\text { - Accelerate development of additional late-successional habitat in matrix land } \\
\text { outside of reserves by thinning. } \\
\text { - Protect critical habitat structures (e.g., snags and nest trees). } \\
\text { - Consider policy changes to allow more management and adaptive } \\
\text { management in late-successional reserves. }\end{array}$ \\
\hline $\begin{array}{l}\text { Increase resilience of } \\
\text { late-successional forests and } \\
\text { surrounding habitat in dry } \\
\text { fire-adapted forests. }\end{array}$ & $\begin{array}{l}\text { - Increase resilience of surrounding forests with thinning and } \\
\text { prescribed burning. } \\
\text { - Increase fuel-reduction treatments in urban growth boundaries. } \\
\text { - Increased use of wildfire for ecological benefits. }\end{array}$ \\
\hline $\begin{array}{l}\text { Increase resistance of } \\
\text { late-successional habitat in } \\
\text { fire-adapted forests strategically } \\
\text { across a large region. }\end{array}$ & $\begin{array}{l}\text { - Protect remnant habitat from fire and insect outbreaks. } \\
\text { - Manage and plan for growth in the wildland-urban interface. } \\
\text { - Increase management of human ignitions sources. }\end{array}$ \\
\hline $\begin{array}{l}\text { Increase habitat connectivity and } \\
\text { permeability in fire-adapted forests. }\end{array}$ & $\begin{array}{l}\text { - Increase use of conservation easements. } \\
\text { - Increase road closures and restrictions on access in critical habitats. } \\
\text { - Accept loss of some ecosystem components to protect others. }\end{array}$ \\
\hline $\begin{array}{l}\text { Increase amphibian population } \\
\text { resilience by reducing } \\
\text { non-climatic threats. }\end{array}$ & $\begin{array}{l}\text { - Reduce non-climatic threats such as invasive species, diseases, artificial } \\
\text { barriers to water flow, and recreation traffic. } \\
\text { - Remove exotic fish. } \\
\text { - Facilitate recovery from past management with habitat manipulation. } \\
\text { - Manage road, trail, and recreation impacts. } \\
\text { - Maintain hydrology of critical habitats. } \\
\text { - Increase habitat connectivity and heterogeneity. }\end{array}$ \\
\hline $\begin{array}{l}\text { Increase amphibian population } \\
\text { resilience to disease and pathogens. }\end{array}$ & $\begin{array}{l}\text { - Manage for decreased snowpack. } \\
\text { - Educate the public about disease sensitivities. } \\
\text { - Limit recreation and other use through restrictions or closures. }\end{array}$ \\
\hline $\begin{array}{l}\text { Increase resilience of wetland habitat } \\
\text { to changes in temperature and } \\
\text { hydroperiod by enhancing } \\
\text { breeding sites. }\end{array}$ & $\begin{array}{l}\text { - Use vegetation to increase shading of wetlands and mircohabitats. } \\
\text { - Retain water levels in wetlands when controlled by reservoir systems. } \\
\text { - Increase microhabitat structures (e.g., woody debris) for microclimate refugia, } \\
\text { nesting habitat, and egg deposition structures. }\end{array}$ \\
\hline $\begin{array}{l}\text { Maintain and protect montane habitat } \\
\text { for American pika, hoary marmot, } \\
\text { and Cascade red fox. }\end{array}$ & $\begin{array}{l}\text { - Monitor tree establishment in montane meadows. } \\
\text { - Remove trees from meadows using fire and mechanical treatments. } \\
\text { - Monitor soil development, cryptobiotic crust, and herbaceous plant } \\
\text { establishment in previously snow-covered and glaciated areas. } \\
\text { - Restrict visitor around montane meadow habitats. }\end{array}$ \\
\hline $\begin{array}{l}\text { Increase population resilience of } \\
\text { subalpine-dependent species. }\end{array}$ & $\begin{array}{l}\text { - Increase education and regulatory enforcement to prevent adverse } \\
\text { human-wildlife interactions. } \\
\text { - Augment currently stressed populations of mountain goats from populations } \\
\text { that are larger and more robust. }\end{array}$ \\
\hline
\end{tabular}


Montane meadow habitats and associated wildlife species in the North Cascades will likely experience changes as temperature increases. Wet montane meadows, maintained by snowpack in the winter and short growing seasons in summer, will likely decrease as lower snowpack and longer growing seasons facilitate tree establishment. Drier meadows may also experience tree encroachment; however, these meadows may be maintained by more fire. Loss of montane meadows would reduce habitat for species such as the American pika (Ochotona princeps Richardson), hoary marmots (Marmota caligata Eschscholtz), and Cascade red fox (Vulpes vulpes cascadensis Merriam). Although relatively few species in the North Cascades exist at the warm or dry extreme of their physiological limits, several species in montane habitats are physiologically limited by warm temperatures and dry summer conditions. For example, the pika is sensitive to warm temperatures and has recently disappeared from several lower elevation sites in parts of its range [31]. With warmer temperatures, species such as the pika will be more restricted in the times of day that they can forage. Decreased snowpack may also affect the pika by providing less insulation while they are in their burrows in the winter.

\subsection{Vulnerabilities and Adaptation Options for Fish and Fish Habitat}

Although watersheds in and adjacent to the North Cascade have some of the best salmonid habitats and most productive and diverse fish populations in the continental United States, several existing and emerging issues may threaten fish and fish habitat in this region. NCAP participants focused on three impact pathways through which changes in climate will likely affect fish populations and habitats: changes in timing and increased magnitude of peak flows, lower low flows in summer, and warmer water temperatures. If fish populations cannot adapt to rapidly changing habitat conditions or conditions that are outside the historical range of variability, then these changes in climate will reduce the quality and quantity of freshwater habitat.

Peak flows in winter are projected to increase for many watersheds in the North Cascades, particularly in mid-elevation basins that receive winter precipitation as both rain and snow $[13,32]$. Increases in the magnitude of winter flooding will likely reduce egg-to-fry survival rates for pink (Oncorhynchus gorbuscha Walbaum), chum (O. keta Walbaum in Artedi), sockeye (Oncorhynchus nerka Walbaum), chinook, and coho (Oncorhynchus kisutch Walbaum) salmon due to increased intensity and frequency of redd and egg scouring, although the effects of higher peak flows in winter will differ across species and populations. Higher peak flows can also reduce availability of slow-water habitats, which can flush rearing juveniles downstream from preferred habitats and subsequently reduce freshwater survival rates. Workshop participants identified adaptation tactics to increase habitat resilience to higher peak flows including restoring spawning habitat and removing migration barriers, thereby increasing access to more spawning habitat (Table 4).

The largest reductions in low summer flows are projected for streams on the western slopes of the Cascades, but reductions are also projected for streams on the eastern slopes of the Cascades [32]. In combination with higher summer water temperatures, reduced summer flow will limit rearing habitat for salmon with stream-type life histories (in which juveniles rear in freshwater for one or more years) and increase mortality during spawning migrations for summer-run adults. Participants identified adaptation tactics to increase resilience of aquatic habitat to low summer flows, 
including restoring structure and function of stream channels and managing upland vegetation to retain snow and water, thereby slowing spring runoff (Table 4).

Table 4. Adaptation strategies and tactics for fish and fish habitat in the North Cascades.

\begin{tabular}{|c|c|}
\hline Adaptation strategy & Adaptation tactics \\
\hline $\begin{array}{l}\text { Increase spawning habitat } \\
\text { resilience to higher peak } \\
\text { flows by restoring stream } \\
\text { and floodplain structure } \\
\text { and processes. }\end{array}$ & $\begin{array}{l}\text { - Restore stream and floodplain complexity. } \\
\text { - Provide alternative habitat for spawning. } \\
\text { - Increase protection of alternative spawning habitat. } \\
\text { - Consider removing natural barriers to increase access to spawning habitat. } \\
\text { - Protect habitat by increased use of engineered log jams where feasible. }\end{array}$ \\
\hline $\begin{array}{l}\text { Increase habitat resilience to } \\
\text { higher peak flows by } \\
\text { reducing threats from roads } \\
\text { and infrastructure in } \\
\text { the floodplain. }\end{array}$ & $\begin{array}{l}\text { - Designate and restore natural floodplains and associated habitat. } \\
\text { - Increase floodplain habitat. } \\
\text { - Remove infrastructure from floodplains. } \\
\text { - Disconnect roads from streams. } \\
\text { - Reduce road density near streams. } \\
\text { - Increase culvert capacity. } \\
\text { - Reduce flashiness of peak flows. }\end{array}$ \\
\hline $\begin{array}{l}\text { Increase aquatic habitat } \\
\text { resilience to low } \\
\text { summer flows. }\end{array}$ & $\begin{array}{l}\text { - Increase off-channel habitat and refugia in side channels and channels fed } \\
\text { by wetlands. } \\
\text { - Protect wetland-fed streams which maintain higher summer flows. }\end{array}$ \\
\hline $\begin{array}{l}\text { Manage upland vegetation } \\
\text { to retain water and snow, } \\
\text { slowing spring snow melt } \\
\text { and runoff. }\end{array}$ & $\begin{array}{l}\text { - Increase forest cover to retain snow and decrease snow melt. } \\
\text { - Restore mid- and high-elevation wetlands that have been altered by past } \\
\text { management. }\end{array}$ \\
\hline $\begin{array}{l}\text { Increase habitat resilience } \\
\text { for cold-water fish sensitive } \\
\text { to warmer temperatures by } \\
\text { restoring structure and } \\
\text { function of streams. }\end{array}$ & $\begin{array}{l}\text { - Increase habitat and refugia in side channels. } \\
\text { - Protect wetland-fed streams, which maintain higher summer flows. } \\
\text { - Restore structure and heterogeneity of stream channels. } \\
\text { - Reconnect floodplains. } \\
\text { - Remove dikes and levees. } \\
\text { - Restore and protect riparian vegetation. }\end{array}$ \\
\hline $\begin{array}{l}\text { Increase understanding of } \\
\text { thermal heterogeneity in } \\
\text { streams and } \\
\text { cold-water refugia. }\end{array}$ & $\begin{array}{l}\text { - Identify and inventory cold water refugia, springs, and groundwater input } \\
\text { to streams. } \\
\text { - Identify seasonal refugia (winter and summer). } \\
\text { - Study the influence of lakes, reservoirs, and groundwater on stream temperatures. } \\
\text { - Study how fish use thermal refugia. }\end{array}$ \\
\hline $\begin{array}{l}\text { Increase resilience of native } \\
\text { fish species by reducing } \\
\text { barriers to native species } \\
\text { migration and removing } \\
\text { nonnative species. }\end{array}$ & $\begin{array}{l}\text { - Remove or control nonnative fish species. } \\
\text { - Assess migration barriers and potential new habitat for native species. } \\
\text { - Remove barriers to fish passage where this will not increase threats from } \\
\text { nonnative species. } \\
\text { - Maintain or construct barriers to prevent spread of nonnative species. }\end{array}$ \\
\hline
\end{tabular}


Water temperature is a key aspect of water quality for salmonids, and excessively high temperature affects their distribution, migration, and health, inhibiting salmon migration and breeding patterns and reducing cold-water refugia and connectivity. Projected future air and water temperatures in August at a number of sites on the west slopes of the North Cascades are likely to be high enough to move streams from favorable to stressful categories of thermal rearing habitats for salmonids, but a few sites remain favorable [32]. Climate change is also projected to increase the frequency and persistence of thermal migration barriers for salmon. It is likely that a warmer climate will reduce the availability of cold-water refugia in some basins in the North Cascades. Participants identified adaptation tactics to reduce thermal stress on fish populations and protect cold-water refugia (Table 4). Additional research to identify locations of cold-water refugia and how fish use refugia can inform efforts to adapt habitat restoration in a changing climate.

\section{Conclusions}

\subsection{A Successful Science-Management Partnership}

The NCAP made significant progress on responding to climate change on public lands in the North Cascades region by contributing a synthesis of scientific information and potential management solutions and catalyzing a collaboration of land management agencies and other stakeholders seeking to address climate change in north-central Washington. The partnership, educational workshops, vulnerability assessment, and adaption planning of the NCAP enabled the national forests and national parks to accomplish several elements of their agency climate change response strategies.

Vulnerability assessment and adaptation are critical components of responding to climate change for land management agencies. The NCAP vulnerability assessment used the best available science on climate change and local effects to identify vulnerabilities of infrastructure, species, habitats, and ecosystems processes in the North Cascades region. Based on these vulnerabilities, a "menu" of adaptation options was developed that can be incorporated into existing programs and plans for each resource sector.

The science-management dialog identified management practices that, in their current form or with slight modifications, are useful actions for increasing resilience, as well as new management practices for adaptation. For example, road engineers in the national forests and national parks already have a process through which they are making decisions about which roads to maintain and which ones to decommission, but standards for the size of culverts can be modified to accommodate increased frequency and magnitude of flooding expected with climate change. In vegetation management following fire, silviculturists have existing standards for replanting native tree species, but may now plant nursery stock outside of the current seed zone that are tolerant of higher temperatures or lower soil moisture. In wildlife management, existing standards for "no touch" in late-successional forest habitat are being reconsidered relative to active management of fuels to reduce severity of wildfires, which are expected to increase in a warmer climate. In fisheries management, a wide range of habitat enhancement projects are underway, but now cold-water refugia are being emphasized because of the anticipated increase in stream temperature in the future. 
Given the currently limited resources available to implement adaptation, resource managers will need to prioritize this menu of options. Furthermore, the adaptation options developed by NCAP provide a platform to encourage continued work to apply these strategies and tactics to specific locations. Many adaptation options may be best implemented when management plans are revised or as threats emerge, although it will be important to consider these options before the effects of climate change are fully realized.

The NCAP process has relevance beyond only north-central Washington and the climate change response strategies of the USFS and NPS. The scientific information synthesized through the NCAP process is relevant for other land management agencies and stakeholders in the region. Many of the adaptation options are likely applicable throughout the Pacific Northwest and beyond and they can provide a starting point for adaptation planning in other locations. Furthermore, the science-management partnership can potentially be implemented by any organization. Similar to past adaptation efforts [7], a strong science-management connection was critical to the success of the NCAP, and we encourage others to emulate this approach as a foundation for increasing climate change awareness, assessing vulnerability, and developing adaptation plans.

We offer additional suggestions for organizations that may be considering a similar partnership to assess vulnerability and develop adaptation options. The outcomes of the process will be more satisfactory if organizers consider breadth $v s$. depth at the beginning of the process. The NCAP intentionally assessed a wide range of resources (hydrology, vegetation, wildlife, and fish), but as a consequence, the depth of analysis on any one resource was less than it would have been had we focused on a single resource. Similarly, careful consideration of the stakeholders involved will determine if the process focuses on policies and management actions of a single agency or develops a diverse adaptation options that are applicable to multiple agencies with different mandates and objectives. Including multiple stakeholders is beneficial for developing an "all lands" approach to adaptation, but an inclusive process may produce adaptation options that are less specific to the management framework of any one agency. Science-management partnerships require time and effort on the part of scientists and managers. The likelihood of success increases when agency leadership supports the process by encouraging involvement of staff and allowing them time to engage in the process.

\subsection{Challenges and Next Steps}

The NCAP expanded on previous science-management partnerships by creating an inclusive forum through which local and regional stakeholders could discuss cross-boundary issues related to vulnerability and adaptation, but more work is needed to truly achieve an "all lands" approach to adaptation as called for by many land management agencies. The agencies involved had different mandates and objectives and were at different stages in the process of responding to climate change, and although these differences allowed agencies to share approaches and learn from the experiences of others, they presented challenges for the development of collaborative adaptation plans. Land management agencies in the North Cascades collaborate on many cross-jurisdictional issues and it was difficult to determine the appropriate partners to include in this process. An all-lands approach 
may be more effectively achieved by considering climate change in existing partnerships that are already focused on a single issue or a narrow range of issues.

The most important and potentially most challenging next step is to implement adaptation strategies and tactics in resource management plans and programs. We anticipate that implementation will occur gradually over time, with major advances occurring as specific needs arise or in response to disturbances, extreme events, plan and program revisions, and changes in policies and regulations. As with the initial planning process, implementation will require collaboration among multiple land owners and management agencies in the region.

In some cases, similar adaptation options were identified for more than one resource sector, suggesting a need to synthesize and integrate adaptation planning across disciplines. Examples include coordinating adaptation of vegetation management with that of wildlife habitat, and coordinating adaptation of infrastructure design with management of fish habitat. Adaptation options that provide benefits to more than one resource are likely to have the greatest effect and are thus more likely to be implemented [7]. Conversely, some adaptation options involve tradeoffs (e.g., some actions may facilitate adaptation for one resource at the expense of another) that could be explored in greater detail to prevent unintended consequences. The NCAP resource sector workshops included specialists from related disciplines, and integrative concepts were discussed and explored, but an important next step is to develop multi-disciplinary teams to explore tradeoffs and benefits.

Similar to a recent national perspective on the role of climate change adaptation in federal agencies [3], we have an optimistic vision for how the adaptation process will evolve in the North Cascades region:

- Climate change will be incorporated in planning, projects, and on-the-ground activities similar to how other stressors such as fire, insects, and human activities are currently addressed in resource management.

- Assessments of the effects of climate change and other natural and human factors on ecosystems will be periodically developed, including updated scientific documentation.

- Monitoring activities will include indicators that detect the effects of climate change on species and ecosystems, and monitoring data will be used to make periodic adjustments in planning and project management.

- Agency planning processes will be sufficiently flexible that climate change assessments and management objectives will be used to identify opportunities for managing across boundaries.

- Effects of climate change on ecosystem services will be examined to determine if near-term management options can reduce undesirable future effects.

- Restoration activities will be designed and implemented in the context of the potential influence of climate change on the success of those activities.

- Institutional capacity for adaptation will increase within federal agencies as resource managers acquire technical expertise on climate change and increasingly communicate with scientists to implement "climate smart" management.

Implementing this vision will not be easy. It will require (1) a sustained commitment and partnership of federal agencies, adjacent land owners and stakeholders over a decade or more, (2) incorporation of climate-smart principles, strategies, and actions in standard agency planning documents to enable implementation on the ground, and (3) sufficient financial resources to make 
critical adjustments in management policies and practice to accommodate adaptation. Above all, climate change needs to become a standard consideration in policy, management, and decision making. Over the past 25 years, resource management in the Pacific Northwest has transitioned from a dominant theme of resource extraction (primarily timber harvest) to ecosystem-based management and restoration. Including climate change as a component of management is relatively easy compared to that transition.

The USFS and NPS are in transition from viewing climate as unchanging to viewing climate as dynamic and mediating changes in the environment [3,7,21]. Evolving science and climate policy, combined with near-term changes in ecosystems will necessitate iterative evaluation of adaptation options for land management. We are currently being deluged by new information about the effects of a changing climate on ecosystems. Resource managers are observing changes in weather and ecological disturbances and responding to those changes on the ground, thus learning about adaptation. The NCAP process provided a foundation for selecting and implementing adaptation actions, which can be continually revisited as part of adaptive management in the broadest sense of the term, facilitating the functionality of ecosystem processes in preparation for a warmer world.

\section{Acknowledgments}

We thank the many scientists and resource managers who attended the workshops and contributed to making the North Cascadia Adaptation Partnership a success. Several people contributed ideas and materials to the full government report that was a product of the NCAP process including Michael Case, Alan Hamlet, Joshua Lawler, Jeremy Littell, Kailey Marcinkowski, Nathan Mantua, Maureen Ryan, and Ronda Strauch. Figure 1 was created by Robert Norheim. Funding for this project was provided by the USDA Forest Service, Pacific Northwest Research Station and the National Park Service.

\section{Conflict of Interest}

The authors declare no conflict of interest.

\section{References}

1. Intergovernmental Panel on Climate Change. Summary for policymakers. In Climate Change 2007: Impacts, Adaptation and Vulnerability: A Contribution of Working Group II to the Fourth Assessment Report of the Intergovernmental Panel on Climate Change; Parry, M.L., Canzianai, O.F., Palutikof, J.P., Eds.; Cambridge University Press: Cambridge, UK, 2007; pp. $7-$ 22.

2. Climate Change 2007: The Physical Science Basis. Contribution of Working Group I to the Fourth Assessment Report of the Intergovernmental Panel on Climate Change; Solomon, S., Quin, D., Manning, M., Chen, Z., Marquis, M., Averyt, K.B., Tignor, M., Miller, H.L., Eds.; Cambridge University Press: Cambridge, UK, 2007; p. 996.

3. Peterson, D.L.; Millar, C.I.; Joyce, L.A.; Furniss, M.J.; Halofsky, J.E.; Neilsom, R.P.; Morelli, T.L. Responding to Climate Change in National Forests: A Guidebook for Developing 
Adaptation Options; General Technical Report PNW-GTR-855; U.S. Department of Agriculture, Forest Service, Pacific Northwest Research Station: Portland, OR, USA, 2011; p. 109.

4. Swanston, C.W.; Janowiak, M.; Iverson, L. Ecosystem Vulnerability Assessment and Synthesis: A Report from the Climate Change Response Framework Project in Northern Wisconsin; General Technical Report NRS-82; U.S. Department of Agriculture, Forest Service, Northern Research Station: Newtown Square, PA, USA, 2011; p. 142.

5. Morelli, T.L.; Yeh, S.; Smith, N.M.; Hennessy, M.B.; Millar, C.I. Climate Project Screening Tool: An Aid for Climate Change Adaptation; Res. Pap. PSW-RP-263; U.S. Department of Agriculture, Forest Service, Pacific Southwest Research Station: Albany, CA, USA, 2012; p. 29.

6. Littell, J.S.; Peterson, D.L.; Millar, C.I.; O’Halloran, K.A. U.S. National forests adapt to climate change through science-management partnerships. Climatic Change 2011, 110, 269-296.

7. Halofsky, J.E.; Peterson, D.L.; O’Halloran, K.A.; Hoffman, C.H. Adapting to Climate Change at Olympic National Forest and Olympic National Park; General Technical Report PNW-GTR-844; U.S. Department of Agriculture, Forest Service, Pacific Northwest Research Station: Portland, OR, USA, 2011; p. 130.

8. U.S. Department of Agriculture, Forest Service. Forest Service Strategic Framework for Responding to Climate Change, 2008. Available online: http://www.fs.fed.us/climatechange/ documents/strategic-framework-climate-change-1-0.pdf (accessed on 28 August 2012).

9. National Park Service. National Park Service Climate Change Response Strategy. Climate Change Response Program 2010. Available online: http://nature.nps.gov/climatechange/ docs/NPS_CCRS.pdf (accessed on 28 August 2012).

10. Mote, P.W.; Salathé, E.P. Future climate in the Pacific Northwest. Climatic Change 2010, $102,29-50$.

11. Littell, J.S.; Elsner, M.M.; Mauger, G.S.; Lutz, E.R.; Hamlet, A.F.; Salathé, E.P. Regional Climate and Hydrologic Change in the Northern U.S. Rockies and Pacific Northwest: Internally Consistent Projections of Future Climate for Resource Management; Preliminary project report USFS JVA 09-JV-11015600-039; University of Washington, Center for Science in the Earth System, Joint Institute for the Study of the Atmosphere and Ocean, Climate Impacts Group 1: Seattle, WA, USA, 2011.

12. Special Report on Emissions Scenarios, Working Group III, Intergovernmental Panel on Climate Change (IPCC); Nakicenovic, N., Stewart, R., Eds.; Cambridge University Press: Cambridge, UK, 2000; pp. 595.

13. Elsner, M.M.; Cuo, L.; Voisin, N.; Deems, J.S.; Hamlet, A.F.; Vano, J.A.; Mickelson, K.E.B.; Lee, S.; Lettenmaier, D.P. Implications of 21 st century climate change for the hydrology of Washington State. Climatic Change 2010, 102, 225-260.

14. Climate Change 2007: Impacts, Adaptation, and Vulnerability; Contribution of Working Group II to the fourth Assessment Report of the Intergovernmental Panel on Climate Change; Parry, M.L., Canzianai, O.F., Palutikof, J.P., van der Linden, P.J., Hanson, C.E., Eds.; Cambridge University Press: Cambridge, United Kingdom, 2007; p. 976.

15. Scanning the Conservation Horizon: A Guide to Climate Change Vulnerability Assessment; Glick, P., Stein, B.A., Edelson, N.A., Eds.; National Wildlife Federation: Washington, DC, USA, 2011; p. 176. 
16. Lawler, J.; Case, M. Climate Change Sensitivity Database. Available online: http://climatechangesensitivity.org/ (accessed on 28 August 2012).

17. Baron, J.S.; Gunderson, L.; Allen, C.D.; Fleishman, E.; McKenzie, D.; Meyerson, L.A.; Oropeza, J.; Stephenson, N. Options for national parks and reserves for adapting to climate change. Environ. Manage. 2009, 44, 1033-1042.

18. Joyce, L.A.; Blate, G.M.; McNulty, S.G.; Millar, C.I.; Moser, S.; Neilson, R.P.; Peterson, D.L. Managing for multiple resources under climate change. Environ. Manage. 2009, 44, 1022-1032.

19. Millar, C.I.; Stephenson, N.L. Climate Change and forests of the future: managing on the face of uncertainty. Ecol. Appl. 2007, 17, 2145-2151.

20. Heller, N.E.; Zavaleta, E.S. Biodiversity management in the face of climate change: A review of 22 years of recommendations. Biol. Conserv. 2009, 142, 14-32.

21. Forest Adaptation Resources: Climate Change Tools and Approaches for Land Managers; Gen. Tech. Rep. NRS-GTR-87; Swanston, C.W., Janowiak, M.K., Eds.; U.S. Department of Agriculture, Forest Service, Northern Research Station: Newtown Square, PA, USA, 2012; p. 108.

22. Hamlet, A.F.; Lettenmaier, D.P. Effects of 20th century warming and climate variability on flood risk in the western US. Water Resour. Res. 2007, 43, W06427.

23. Tohver, I.; Hamlet, A.F. Impacts of 21 st Century Climate Change on Hydrologic Extremes in the Pacific Northwest Region of North America Chapter 7. In Final Report for the Columbia Basin Climate Change Scenarios Project; Climate Impacts Group, University of Washington: Seattle, Washington, USA, 2010. Available online: http://www.hydro.washington.edu/2860/ (accessed on 28 August 2012).

24. Littell, J.S.; Oneil, E.E.; McKenzie, D.; HIcke, J.A.; Lutx, J.A.; Norheim, R.A.; Elsner, M.M. Forest ecosystems, disturbance, and climatic change in Washington State, USA. Climatic Change 2010, 102, 1-2.

25. Hellmann, J.J.; Byer, J.E.; Bierwagen, B.G.; Dukes, J.S. Five potential consequences of climate change for invasive species. Conserv. Biol. 2008, 22, 534-543.

26. Rogers, B.M.; Neilson, R.P.; Drapek, R.; Lenihan, J.M.; Wells, J.R.; Bachelet, D.; Law, B.E. Impacts of climate change on fire regimes and carbon stocks of the U.S. Pacific Northwest. J. Geophys. Res. 2011, 116, G03037.

27. Theurillat, J.P.; Guisan, A. Potential impact of climate change on vegetation in the European Alps: A review. Climatic Change 2001, 50, 77-109.

28. Hessburg, P.F.; Agee, J.K.; Franklin, J.F. Dry forests and wildland fires of the inland Northwest, USA: Contrasting the landscape ecology of pre-settlement and modern eras. Forest Ecol. Manag. 2005, 211,117-139.

29. Corn, P.S. Climate change and amphibians. Anim. Biodivers. Conserv. 2005, 28, 59-67.

30. Blaustein, A.R.; Romansic, J.M.; Scheessele, E.A.; Han, B.A.; Pessier, A.P.; Longcore, J.E. Interspecific variation in susceptibility of frog tadpoles to the pathogenic fungus Batrachochytrium dendrobatidis. Conserv. Biol. 2005, 19, 1460-1468.

31. Beever, E.A.; Brussard, P.F.; Berger, J. Patterns of apparent extirpation among isolated populations of pikas (Ochotona princeps) in the Great Basin. J. Mammal. 2003, 84, 37-54. 
32. Mantua, N.; Tohver, I.; Hamlet, A.F. Climate change impacts on streamflow extremes and summertime stream temperature and their possible consequences for freshwater salmon habitat in Washington state. Climatic Change 2010, 102, 187-223.

(C) 2013 by the authors; licensee MDPI, Basel, Switzerland. This article is an open access article distributed under the terms and conditions of the Creative Commons Attribution license (http://creativecommons.org/licenses/by/3.0/). 